\title{
Solve the Problem or Escape Responsibility? The Politics of Chinese Privatization Reform
}

\author{
Yutao Huang ${ }^{1}$ (1)
}

Received: 4 January 2018 / Accepted: 2 August 2018 / Published online: 24 August 2018

(c) The Author(s) 2018

\begin{abstract}
This article investigates the Chinese privatization reform in the late 1990s, when the privatizations were implemented among small- and medium-sized state-owned enterprises and pushed by the local governments. Even though the Chinese privatization reform has been intensively discussed, few studies can fully explain how China's local governments could increase fiscal surpluses through privatization under the condition that the policy burden of redundant workers was persistent. Hence, this paper proposes three hypotheses that reflect different motivations of the local governments. Testing the hypotheses via the method of process tracing for causal inference, I find that due to comparatively fewer subsidy payments, China's local governments could have a fiscal surplus after privatization reform. By unveiling the mechanism, this article can help people to understand why China's central and local governments had conflicting interests in the process of privatization. More importantly, it re-evaluates the role of China's local government in the process of privatization. The original intention of the local government was to escape the responsibility of paying subsidies rather than solve the problem of bad performance in state-owned enterprises.
\end{abstract}

Keywords Chinese privatization reform · Local government · Central-local relations $\cdot$ Political economy

\section{Introduction}

China's economic transition since 1978 has drawn considerable attention, and a key to China's transformation from a central planning economy to a market economy lies in its reform of state-owned enterprises (SOEs). There is no doubt that when reform started in late 1978, SOEs dominated China's industrial sectors in every aspect,

Yutao Huang

yutao.huang@politics.ox.ac.uk

1 Department of Politics and International Relations, University of Oxford, Manor Road,

Oxford OX1 3UQ, UK 
while now, they barely account for $30 \%$ of GDP outputs and $17.2 \%$ of employment. Initially, China's government tried various measures to attempt to increase SOEs' performance, including retained profit (liu cun shou yi), tax instead of profit remittance (li gai shui), and contracting systems. Concerning the crush of the state-owned economy since 1986, the State Council published a new guideline for SOE reform, which proposed that they 'retain control of large enterprises and gradually retreat from small and medium-sized enterprises' (Liu et al. 2006). The privatization of SOE was firstly implemented at Zhucheng City, Shandong Province, in 1993. Since being confirmed by the then prime minister Zhu Rongji, privatization was quickly adopted by other cities and it became mainstream for China's local governments to reform SOEs. Thus, understanding how China's small and medium-sized SOEs were privatized is essential in grasping how China transitioned from a central planning economy to a market economy.

During the period from 1997 to 1999 , China's local governments massively privatized small and medium enterprises (SMEs) and some problems emerged during this process. However, few articles have completely explained how local governments could obtain fiscal surplus when concerned with the policy burden of redundant workers. In this article, I argue that due to comparatively fewer subsidy payments, China's local government could have more fiscal surplus after privatization. Importantly, I try to reveal that the original intention of the local governments was to escape the responsibility of subsidizing firms rather than solve the problem of SOEs' bad performance. The research method is process tracing tests for causal inference and the time frame is the period between 1997 and 1999, when the privatization of small and medium SOEs was processed the fastest in the history of China's economic transition.

This article is divided into six parts. Section two is the literature review, as reviewing previous articles related to China's privatization can help people to understand why the research of privatization is meaningful. The third section includes the research question and hypotheses; in this part, three possible hypotheses are raised concerning how China's local government could increase fiscal revenues. Next, the research method part discusses the method selection and then introduces the method that I chose to test these hypotheses. The fifth chapter is the main body of this paper, and through examining the three hypotheses, respectively, I accept the third hypothesis and reject the previous two. Last, I discuss the findings and then give a brief conclusion at the end of the article.

\section{Literature Reviews}

\subsection{The Characteristics of Chinese Privatization Reform}

There are three main characteristics of Chinese privatization reform. The first is that the privatization mainly happened within SMEs. Since the economic performance of SOEs was too weak to be sustainable in the 1990s with the deepening of market reform, these enterprises seemed inadequate to compete with private and foreign firms, which contributed to the incentives of privatizing some of them (Knight 
and Ding 2012). Chinese economic reform adopted a gradualism philosophy that could be reflected by its political slogan "groping the stones to cross the river" and, because of this, a prudent approach was attractive to the reformers. Compared with large enterprises, which are often in natural monopoly industries, small and medium SOEs are mostly located in competitive sectors, such as machinery, electronics, textiles, and food processing (Knight and Ding 2012). Consequently, starting the privatization reform with SMEs not only satisfied the requirements of market reform but also alleviated the impacts on the Chinese socialist nature (Coase and Wang 2012).

The second characteristic is that the privatization of SMEs intensively happened in the time between 1997 and 1999. As the data released by the China Statistical Yearbook indicate, by August 1998, 47,613 SMEs were privatized, representing $64 \%$ of all registered SOEs. The figure below illustrates the total number of SOEs and the corresponding employees by the National Bureau of Statistics. Noticeably, there are sharp declines both in the amount of SOEs and the number of employees in the time between 1997 and 1999. The total units of SOEs dropped from the peak amount of approximately 1.2 million to only five hundred thousand, and the total number of state-owned employees fell by over 10 million. By 2001 , over $90 \%$ of SMEs had successfully reformed (Shao 2014). Thus, it is not exaggerating to say that the 3 years $(1997,1998,1999)$ saw a critical time point in the process of Chinese privatization reform.

The third characteristic is that Chinese local governments acted as the driving force underlying this round of privatization reform. After the decentralization of administration in 1979, China's local governments had autonomy for directing local economies (Naughton 2008). Small and medium SOEs are under the supervision of local government, while large SOEs are under the control of the central government. Because of this governing structure, it was impossible to push such a largescale privatization program without the participation of the local governments. Qian and Weingast (1997) claim that Chinese privatization was led by the local government rather than the central government. Zhang (2009: 7) contends that China's economic transition was indeed "reform from the grassroots" and the term "grassroots" refers to local governments compared to the central government. The majority of the local governments massively privatized the SMEs that belonged to their local area. For instance, Heze City, Shandong Province, had privatized 97\% of SOEs within 4 years.

\subsection{The Role of Local Governments}

As privatization reform is a critical part of the Chinese economic reform, there are intensive discussions about this issue within Chinese scholarship. Conventional wisdom agrees that the inter-government decentralization, cadre evaluation system, and re-centralization of the fiscal system in reforming China led to the privatization reform. After Mao's era, China's local governments had gained a certain degree of policy autonomy. The decentralization of policy making was intended to stimulate the initiatives of the local governments to develop the economy. Because of this, 
many scholars contend that the inter-government decentralization in China is quasifederalism. For instance, Montinola et al. (1995) characterizes the Chinese political system as 'federalism, Chinese style' or 'market-preserving federalism'. Zheng (2007) claims that although it is without any constitutional document, China is de facto federalism because local governments exclusively handle most economic issues. This quasi-federalism structure is a precondition for privatization reform, as it reflects the autonomy of local governments to produce innovative policies independently.

Next, the cadre evaluation system motivated the revenue-seeking characteristic of local governments. Because of the cadre evaluation system in reforming China, "local leaders in the Chinese nomenklatura have a perfectly stable set of expectations regarding the promotion criteria, and GDP, fiscal revenues, and economic growth rate are a set of essential criteria for promotion" (Liu et al. 2006: 7). This institution strongly strengthened the incentives of local governments to promote economic development and compete with each other. Chinese economic system was constituted by "local governments with corporate characteristics", in which the secretary of the municipal party committee acted as the chairman, the mayor acted as the general manager, and goal of the government was to increase the GDP growth rate just like that of the company to improve the business profits (Oi 1995). Thus, as with the findings provided by Guo and Yao (2005), the intensification of the crossregional competition after the market reform in 1979 forced local governments to develop the local economy in pursuit of higher GDP and fiscal revenues than those of their neighboring competitors.

Last, given the revenue-seeking characteristic of the local governments, the recentralization of the fiscal and monetary system in the 1990s triggered their proprivatization attitude. In the 1980 s, local governments enjoyed considerable autonomy toward the income rights-tax and profit collection (Qian and Xu 1993). As local governments could influence the local bank credit decisions, short-term GDP figures could be boosted through pumping money into massive investment programs or subsidizing loss-making SOEs (Lardy 1998). However, after the re-centralization of the banking system in the 1990s, especially the tax reform (fenshui zhi) in 1994 which institutionalized the division of tax revenues between the central and local governments (Qian and Roland 1998; Li et al. 2000), local governments then had less influential power on the bank loans in their own jurisdictions. The re-centralization imposed hard budget constraints on the local financial budget and, after that, they had to develop local economies for obtaining more fiscal revenues (Cao et al. 1999).

Many scholars appreciate the contributions made by the local governments, not only in the privatization reform but also in China's market reform in general. China's economic reform is treated as a 'bottom-up reform' or 'wisdom of grassroots'. Oi (1995) claims that local officials facilitated China's market production within a local corporatist context. Rawski (1995) contends that the gradual reform was initiated but not directed by the central government; conversely, it was precisely the courage and wisdom of the local governments which explored the path of reform and cultivated the pro-reform sentiments in a bottom-up way. Zheng (2007) argues that the central and local governments had conflicting attitudes toward the pace and extent of reform, and the latter had received little help at the beginning of the 
reform. However, the success of the partial reform forced the central government to implement nationwide reform policies. Therefore, given the combined effects of the institutions mentioned above, local governments are considered as the pioneers in reforming China and have gained a positive historical evaluation.

\subsection{The Puzzle of Continued Subsidy Payments}

It is widely accepted that the privatization of SMEs in China was implemented for pursuing explicit material benefits. Liu et al. (2006:10) state that "as a rational revenue-seeking entity, local government will be motivated to allow its firms to be privatized if it expects that privatized firms can induce more revenues". Concerned with the hard budget constraints imposed by the re-centralization, it was not a wise choice to continue subsidizing loss-making SOEs; thus, reforming SOEs was unavoidable (Guo and Yao 2005). Li and Liu (2004) contend that the primary purpose of local governments was to give up the ownership of SOEs to increase their fiscal revenues rather than improve enterprise efficiency. This argument is verified by Wang et al. (2001), through quantitative analysis. Combing a sound data pool containing hundreds of SOE information, they conclude that China's government privatized SOEs for alleviating fiscal pressures: stopping subsidizing loss-making firms or obtaining more revenues through privatization.

However, in transition economies, the subsidies may persist regardless of whether the SOEs are privatized or not. This phenomenon is widely found in socialist transformation countries. For maximizing social welfare, SOEs have been asked to hire unnecessary workers and offer retirement pensions, housing, and medical care services, which are inconsistent with efficiency (Naughton 2008). In this case, the problem of soft budget constraints exists: the state would be responsible for the SOE's losses that arise from the policy burdens; thus, the government is obliged to give additional credits or other resources to enable loss-making SOEs to get rid of their plight. Privatization in nature is the transfer of ownership from the state to the private sector, while the policy burdens cannot be resolved solely through the transfer of ownership (Brada 1996). Thus, after privatization, it is impossible for postprivatized firms to afford the welfare costs regarding healthcare, housing, and aged pension for redundant workers by themselves (Perkins 1998). As a result, as Lin et al. (1998) claim, the privatized firms would call for ex-post policy favors and the government would hardly be able to resist the enterprises' pressures for such favors.

Therefore, if the privatization is implemented without a sound social insurance system, the government must continue subsidizing post-privatized firms to compensate for the burden of redundant workers. Fan (2002) uses a game theory model to explain the consideration of governments: if states do not subsidize privatized firms, these firms will lay off a significant number of redundant workers to make the operation more effective. In the absence of a sound social insurance system, laid-off workers would probably cause social instability, which is unacceptable for the central government. Thus, recognizing that the cost of mass-scale laid-off SOE workers would far exceed the cost of subsidy payments, continuing to subsidize privatized SOEs fits the government's interest. In China, the government allocated a large share 
of the fiscal budget to subsidize privatized firms to compensate redundant workers (Dong and Putterman 2003). According to a survey of 242 privatized firms' managers conducted by Liu et al. (2006), their main difficulty is a lack of sufficient funds to compensate redundant workers. Once privatized firms themselves cannot afford compensation fees, local governments must reallocate their financial budget to subside redundant laid-off workers and become losers in privatization.

This presents a significant puzzle, as if China's government needed to pay subsidies even to post-privatized SOEs, why did China's local governments have such strong incentives to privatize SMEs in the late 1990s? Even though the Chinese privatization reform has been intensively discussed, I think that few scholars have combined the explicit material benefits and the continued subsidies in the analysis. Brada (1996) argues that without a sound social insurance system, the transition economy would slow down the pace of privatization for maintaining social stability. However, it is obviously this theory cannot explain the case of China. I appreciate the work of Bai et al. (2006) for identifying the continued subsidies for post-privatized firms and highlighting the divergent interests between China's central and local governments in privatizing SMEs. In their words (2006: 8), "as the amount of surplus labor in an SOEs increase, the cost of privatization regarding damage to social stability increases". Furthermore, they argue that the negative impact of laying off surplus workers and writing off bad loans is not restricted to local regions (2006: 8): "comparing the changes in costs and benefits, the cost may increase faster than the benefit for higher level governments and slower for lower-level governments". Having said that, why did China's central and local governments suffer different costs, and what is the reason for the unevenly distributed benefits and costs being absent in their analysis?

\section{Research Question and Hypotheses}

Given the revenue-seeking nature of the local governments, the privatization process suggests that the local governments de facto gained fiscal surpluses through the reform. According to the claims of conventional wisdom, a local government will be motivated to promote privatization only because of the possibility of obtaining more revenue rather than other ideological or political reasons. Consequently, looking at the actual large-scale privatization of SMEs that occurred from 1997 to 1999, we can reasonably infer that China's local governments have benefitted from this process. Having said that, if paying subsidies to post-privatized SOEs was inevitable, why China's local governments still had such a strong incentive to privatize SMEs in the late 1990s is a mystery. Therefore, in this article, my research question is: How could China's local governments increase fiscal surpluses through privatizing SMEs under the condition that the policy burden of redundant workers was persistent?

I put forward three alternative hypotheses for this empirical question. Because the subsidies were persistent, regardless of whether SOEs were privatized or not, in this case, local governments' fiscal surplus would come from the revenues generated from privatization minus the fees paid for subsidies. Therefore, it is reasonable to infer that through privatization, China's local governments could generate more 
fiscal revenues or, if possible, pay fewer subsidies. The first hypothesis proposes that the benefit came from the sales revenue of SOEs. As Megginson and Netter (2001: 7) claim, "governments have found the lure of revenue from sales of SOEs to be attractive, which is one reason the policy has spread so rapidly". For instance, the privatization of SOEs had produced sufficient revenues for the South Korean government (OECD 2000); in Latin America, direct revenues from the sale of SOEs were a primary source of government revenue (Chong and De Silanes 2005).

The second hypothesis is attributed to the theory that a profitable privatized firm would contribute more tax revenues to the government. Privatization is often treated as a natural solution to the inefficiency of SOEs and there are two main arguments to support this viewpoint. One is that the advantages of private ownership are based on a fundamental theorem of welfare economics: a competitive equilibrium is Pareto optimal. After privatization, the competition will be more intensified, especially in those areas where the role for the government is the weakest, like SOEs in competitive markets or markets that have already become competitive (Asaftei and Parmeter 2010). The second argument concerns the principle-agent problem in SOEs. As the "agent", managers of SOEs would not have enough incentives to improve the efficiency. Once the moral hazard and conflict of interest arise, the profitability of publicly owned firms would be further reduced (Williamson 2008). Following the logic, the pre- and post-privatized firms would need to show big differences regarding efficiency and profitability. As a result, the profitable privatized firms would contribute more tax revenues to the government (Megginson and Netter 2001).

The third benefit comes from the decline of subsidies payment after privatization. According to Chong and De Silanes (2005: 367), there are four primary components to the fiscal impact of privatization: "the direct revenue generated from the sale; the costs incurred by restructuring before sale; the elimination of the net flow of subsidies and transfers from the government to the SOEs; and the new stream of tax payments generated under private ownership". Thus, apart from sales and tax revenue, the elimination of the subsidies is also a considerable benefit for the government. Suppose that the government could pay fewer grants after privatizing loss-making SOEs, its budget deficit would be reduced. In the competitive sectors, continuing to subsidize those SOEs with poor profitability would cause a sizeable fiscal burden for the government. Thus, to alleviate the negative impacts of continually declining business conditions of SOEs, privatizing parts of unsustainable firms can reduce the costs of maintaining unprofitable SMEs and reduce the local government's fiscal burden (Bai et al. 2006). Table 1 summarizes the three hypotheses.

Table 1 The three hypotheses

H1. Due to the sales revenue of privatization reform, China's local governments could have a fiscal surplus after paying subsidies

H2. Due to increased tax contributions of privatized enterprises, China's local governments could have a fiscal surplus after paying subsidies

H3. Due to comparatively fewer subsidy payments, China's local governments could have a fiscal surplus after paying subsidies 
This is an empirical question at first glance, as it only looks at the increase of fiscal surpluses. However, this question has profound theoretical implications. Frankly speaking, the hypotheses reflect different motivations of the local governments to push privatization reform. The local governments were motivated to gain short-term revenues if the first hypothesis is correct. The second hypothesis is closest to the positive historical evaluation of the local governments: they implemented privatization reform to improve the efficiency of the economy and it is the courage and wisdom of the local governments that allowed them to explore the path of reform. However, if the third hypothesis is correct, we must re-evaluate the role of local governments in the privatization process. After all, the third hypothesis implies that the original intention of the local governments was to escape the responsibility of subsidizing firms rather than to solve the problem of SOEs' bad performance. In addition, this research sheds light on the central-local governments' relations in reforming China. Supposing the local governments could pay fewer subsidies after the liberalization, under the condition of policy burden, other entities must share the payments. As the work of Bai et al. (2006) implies, the central government is a highly possible alternative. Thus, testing the hypotheses could help people to understand the conflicting interests between China's central and local governments in the privatization process.

\section{Research Method}

Since the expected fiscal surplus motivated local governments to implement privatization, the increased fiscal surplus can be treated as a dependent variable and the privatization of SMEs is an independent variable. However, we do not know how a local government could obtain the expected additional fiscal surplus through privatization. In the words of George and Bennett (2005: 206), the task remaining is to "identify the intervening causal process - the causal chain and causal mechanismbetween an independent variable and the outcome of the dependent variable". Using a metaphor given by Bennett and Checkel (2012: 7) to explain our task, "suppose a row of dominoes was lying on the table after they had previously been standing: how could one make inferences about whether the first domino caused the last to fall through a 'domino process', or whether the wind, a bump of the table, or some other force caused the dominoes to fall?" What effects promoted the privatization action (the first domino) and finally led to the increase of fiscal surplus (the last domino)? Was this due to the income of sales revenue, rising tax revenue, or comparatively fewer subsidy payments?

Adopting a suitable and elegant method to test the hypotheses is an essential task for this paper. I think that the quantitative approach is inappropriate in this case for two reasons and the first is the problem of insufficient data. Because the hypotheses are related to the flow of cash of local governments, if we could obtain accurate data about local governments' fiscal accounts, it would be easy to inspect which factors contribute to the fiscal surplus. Specifically, we would need to know how much net revenue local governments did receive by selling the SOEs, how much tax revenue was increased after the privatization, and what the amounts of subsidy payments 
were before and after the privatization. However, it is challenging to find sufficient data, regardless of whether this is at the National Bureau of Statistics of the People's Republic of China or at the Ministry of Finance of the People's Republic. Since the credibility of regression results largely depends on the quality of data, the insufficiency of privatization data in China impedes the applicability of this method.

Next, I believe that the comparative advantage of qualitative analysis could play a role in discovering detailed historical information. Using a panel dataset of 26,153 SOEs in China from 1995 to 1997, Bai et al. (2005) find conflicting attitudes between the central and local governments in the privatization process. Their approach is to treat the privatization of SOEs as the independent variable that equals 1 if an SOE was privatized in 1997 and 0 otherwise, and the affiliation with the government is defined as an ordinal variable. Even though they validate the different possibilities of privatization under the different associations, their regression model cannot explain why central and local governments have different motivations. Thus, providing sufficient information for the underlying mechanism is a crucial task, which cannot be achieved without a detailed qualitative analysis. Treating the time between 1997 and 1999 as a critical time point in the history of Chinese privatization reform, we must determine why some local governments made the privatization decisions at that time. How did the local government weigh the benefits and costs of the privatization reform at that time, how did the central government consider this problem, and why did the central government and the local governments have different attitudes towards this issue? Using qualitative research methods could help us to discover these historical details.

Hence, this paper adopts a new research method, which, to my knowledge, has never been used in previous China studies investigating the privatization reform. Process tracing, a technique developed by George and Bennett (2005), uses the evidence within the intervening process posited by each of the alternative explanations and then tests the validity of each hypothesis. As a methodology firstly used in psychology, it investigates the intermediate steps in a cognitive mental process and then attempts to understand the heuristics through the way that humans make decisions. In political and social science, process tracing is defined as the use of "histories, archival documents, interview transcripts, and other sources to see whether the causal process a theory hypothesizes or implies in a case is, in fact, evident in the sequence and values of the intervening variables in that case" (George and Bennett 2005:6). The essential meaning of the term 'process tracing' in political science refers to the investigation of intermediate steps and then making inferences about possible hypotheses regarding how the political or social affairs took place and how they generated the outcome of interest.

Process tracing is applied to causal inference regarding four empirical tests. According to the formulation of Bennett (2010), who built on the work of Van Evera (1997), the tests are classified according to whether passing the test is necessary and sufficient for confirming the hypothesis. Based on these criteria, Table 2 presents the four tests: the straw-in-the-wind test, the hoop test, the smoking-gun test, and the doubly decisive test. Therefore, the principle idea of process tracing for causal inference is to extract clues through investigating archival documents, interview transcripts, and cases, and then, based on their necessary or sufficient criteria, to 


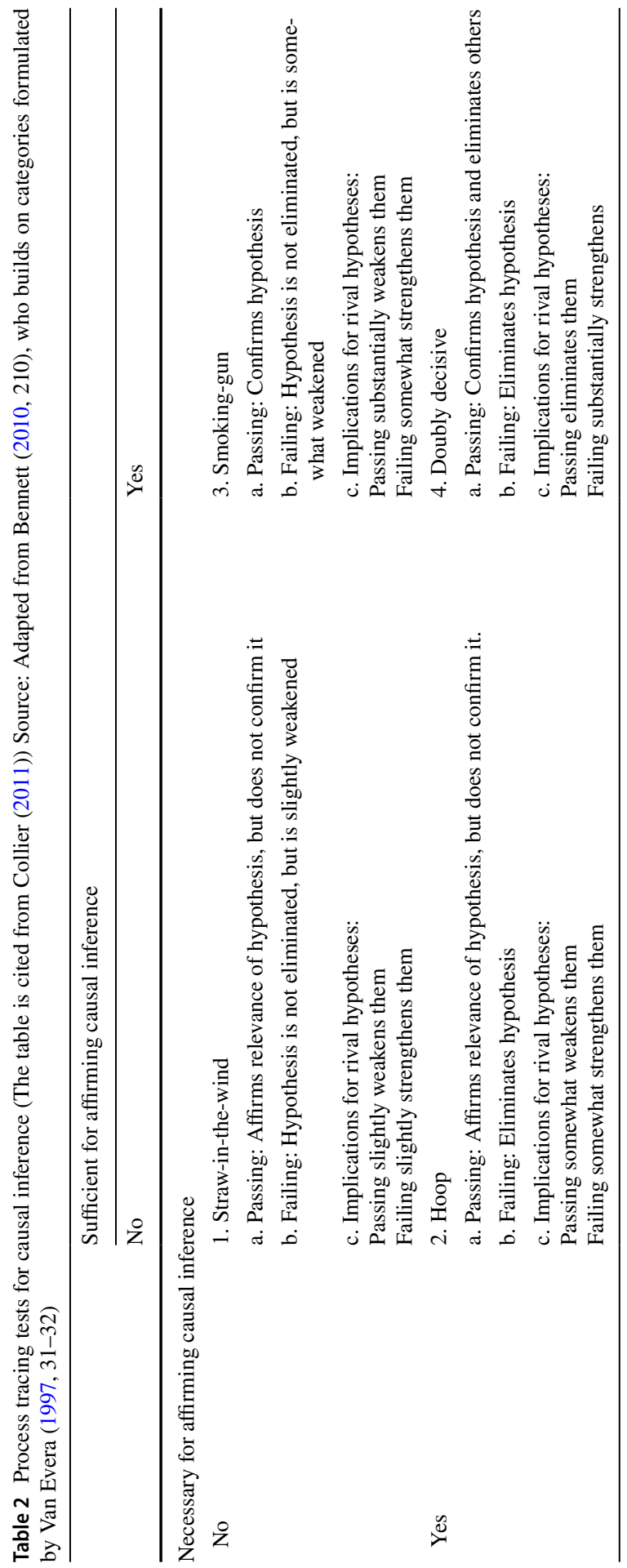


test the hypothesis (Bennett 2010). The table also mentions the implications for rival hypotheses passing each test. If a given hypothesis moves a straw-in-the-wind test, it only slightly weakens the competing explanations; with the smoking-gun test, it substantially weakens them; and with the doubly decisive test, passing eliminates them. If a given hypothesis passes a hoop test, it is not sufficient to confirm this hypothesis; if an explanation fails a hoop test, I will eliminate it from consideration. Therefore, in the following chapters, we will trace clues through investigating the process of privatization of SMEs in China and then use these clues to infer the validity of the three hypotheses, respectively.

However, I must admit that the severe restriction of applying process tracing is the applicability of a causal mechanism. Because the causal mechanism is inferred within a case study, history, or interview transcript, a natural question arises as to whether this mechanism could apply to other cases. Similarly, in King et al.'s (1994) summary, a case study analysis is vulnerable in its generalisability. These criticisms force philosophers of science to think about how many similar cases there are and how frequently recurring the events would need to be to accept a theory. Hedström and Ylikoski (2010: 52) offer a feasible direction for researchers:

It is true that a commitment to explanation via mechanisms means that explanations are always incomplete and provisional, and it is also true that every explanation can be called into question if it can be shown that its hypothesized processes are not evident at a lower or higher level of analysis. Hence, researchers can and do make defensible decisions about when and where to begin and stop in constructing and testing explanations.

Therefore, even though confronting the limitations of this methodology, the potential findings could be more plausible when specifying the time interval of the research. Bennett and Checkel (2014: 29-36) give the standards of proper process tracing; the top four criteria are: "(1) cast the net widely for alternative explanations"; "(2) be equally tough on the alternative explanations"; "(3) make a justifiable decision on when to start"; and "(4) make a justifiable decision on when to stop". I set up the three hypotheses, and each of them receive due treatment. Specifically, to make our explanations more credible, I constrain the time horizon to within 1997-1999, and the findings may be not reliable in explaining the privatizations that happened after 1999. Nevertheless, as a tool of causal inference, the philosophical basis of process tracing signals that it is ontologically consistent with mechanismbased understandings of social reality. If the world is observable, the findings of analyzing typical cases are applicable in explaining matters of the same class.

\section{Testing the Three Hypotheses}

\subsection{Testing the First Hypothesis}

In this chapter, we will test the three hypotheses, respectively. The first hypothesis asserted that even though local governments must subsidize post-privatized firms due to policy burden, with incomes from selling SOEs, local governments could 
Table 3 Nationwide industrial SOEs business condition (1996-1997) Source: National Bureau of Statistics of the People's Republic of China

\begin{tabular}{lccccc}
\hline Type of SOEs & Total amount & $\begin{array}{l}\text { Loss-making } \\
\text { enterprises }\end{array}$ & Total assets & Total liabilities & Total profits \\
\hline 1996 & & & & & \\
Large size & 4946 & 1590 & 3422.34 & 2093.67 & 57.11 \\
Medium size & 10,817 & 4295 & 1001.38 & 724.96 & -7.75 \\
Small size & 71,219 & 23,311 & 851.98 & 617.38 & -8.09 \\
1997 & & & & & 63.19 \\
Large size & 4800 & 1669 & 3976.01 & 2448.65 & -10.33 \\
Medium size & 10,123 & 4373 & 1024.87 & 746.9 & -10.08 \\
Small size & 59,465 & 22,391 & 909.87 & 668.31 & \\
\hline
\end{tabular}

The units of total assets, liabilities and profits are billion

have a fiscal surplus after paying such subsidies. Thus, the profits of selling SOEs could be treated as an intervening variable, which promotes the privatization action (independent variable) and finally leads to the increase of the government's fiscal revenue (dependent variable).

Dating back to China in the 1990 s, we can generate an objective view about the status of SMEs. Even though the performance of SOEs temporarily improved after giving more autonomy during the 1980s, given the competitive pressures of private enterprises and foreign enterprises, a majority of SOEs gradually suffered massive losses. According to the data from NBS (National Bureau of Statistics), Table 3 reflects the plight of SMEs. As Shao (2014) explained, the most significant characteristics of SMEs were the so-called 'Two Highs' — high liabilities and high deficits. While large SOEs could maintain profitability in 1996, both medium and small SOEs suffered massive losses and their losses even expanded in 1997. From the asset-liability ratio, most state-owned SOEs bore a heavy debt burden. Looking at the statistical report, in 1996, the total assets of SMEs were 1.8532 trillion yuan, while the total debt amounted to 1.3422 trillion yuan. The deficit status was even worse in 1997, which increased $30 \%$ within 1 year, and the aggregate losses of SMEs climbed to over negative 20 billion yuan. Compared with the average $61 \%$ asset-liability ratio of large enterprises, the high load rate (over 80\%) would further constrain the profitability and production capacity of SMEs.

The predicaments of SMEs were not confined to one specific city; instead, they were widely distributed within China (Zhu 2003; Zhou 2008; Zhang 2009). Wuhan was a relatively well-developed city in China, and in 1998, its SOEs' liability-toasset ratio was over $100 \%$, and Wuhan's SOEs as a whole was close to the edge of insolvency. Changsha, the provincial capital of Hunan, faced a similar situation as Wuhan: its Municipal Bureau of Finance in 1998 announced that the total assets of local SOEs were 9.9 billion yuan. Hence, with 9.7-billion yuan debt, their assetliability ratio was close to $100 \%$. In Yichang City, Hubei Province, its 28 industrial enterprises, which wholly owned 9.9 billion yuan in assets, were in debt for more than 10 billion yuan, and the nine worst SOEs had over $200 \%$ asset-liability ratios. 
At Zuoquan County, Shanxi province, almost all the SOEs were loss-making, except those offering basic daily life services like the water industry, the electric power industry, and the post office.

To better understand how local governments sold SOEs, we must trace the process of privatization in Heze, the most representative example. Heze is a small city in the southwest of Shandong Province. Its industrial base was fragile and most SOEs were imported from Qingdao and Jinan in the 1960s. To solve the predicament of Heze, Chen Guang, a famous Chinese officer who directed the first case of privatization in Zhucheng, Shandong Province, was appointed as Clerk in 1995. Chen's idea was to duplicate the model of Zhucheng, to privatize SOEs through insider subscription of shares, whereas the plight was worse than the image (Shao 2014). After 3 months' investigation into 305 SOEs, Chen found that Heze's SOEs had extremely high asset-liability ratios. The city's 305 enterprises had total assets of 9.34 billion yuan; thus, with 11.4 billion yuan in debt, the average asset-liability ratio was over $100 \%$. Next, the net assets of SOEs shrank quickly. Financial statements illustrated that net holdings within Heze in 1996 were 15.8 billion yuan, while in 1997, they plunged to 7.6 million. Most seriously, through checking the corporate accounting statements, an audit revealed that over $80 \%$ of financial reports were inaccurate. For instance, one SOE reported 723 million in profit, while it lost 360 million yuan in that year. In sum, industrial SOEs throughout the region were on the edge of collapse.

Concerned with this grim challenge, Chen had to find a pragmatic approach to solve the problem. In August 1997, the Heze government published its reform blueprint and decided to sell SOEs to the private sector. However, due to the high assetliability ratio and awful operational performance, it was impossible to sell SOEs at a high price. For instance, one SOE had 620 million yuan of assets, while its debt was over 700 million yuan; thus, the net assets were even below zero. In other words, the ownership of such SOEs seemed worthless. To privatize SOEs as soon as possible, the Heze government had to sell SOEs at meager prices or even free of charge. As Chen said in 1998, "as long as you can give our workers job for work, food for eating, I will give you the ownership of SOEs". It was not an easy decision at that time, as none of the local governments had freely sold state-owned assets before. Criticisms emerged after 1998, which pointed out that Heze's privatization model was suspected to have caused losses of state-owned assets (Zhu 2003). However, this decision fit the interests of Heze. Even though SOEs were sold nominally very cheaply, given the debt burden and high asset-liability ratio, it was not a bad deal for the government. As Chen said, "for SOEs with huge liability and debt, even if sells them free of charge, it is also difficult to find people who willing to take over it". Therefore, "rather than be called as sending SOEs freely, what we did, in reality, was to throw away the burden and debt" (Shao 2014: 141). After this model was confirmed by then-premier Zhu Rongji in Oct 1998, selling SOEs at low prices was rapidly popularized among other pilot cities (Zhu 2001).

By tracing the privatization process in Heze, we find an essential clue that local governments sold their SOEs at considerably low prices or even free of charge. With this clue, the first hypothesis could be inspected through the hoop test, and Table 4 reflects our inference process. According to the first hypothesis, for the revenues 
Table 4 Hoop test

H1. Due to the sales revenue of privatization reform, China's local governments could have a fiscal surplus after paying subsidies

Clue. Local government sold their belonged SMEs at considerably low prices or even free of charge

Inference. No matter how much subsidies need to pay for privatized enterprises, without sufficient sales revenue, it would be impossible for a local government to have a fiscal surplus after paying subsidies

Summary. With a strong interpretation, H1 fails this hoop test

created by selling SOEs, local governments could have a fiscal surplus after paying post-privatization subsidies. No matter how much subsidies need to be paid to privatized firms, this hypothesis implies that the amount of sales revenue must exceed the grants. Thus, a significant amount of income from the sale must be a necessary condition. In other words, the sales revenue of privatization itself would not positively lead to the increase of fiscal surplus, while without sufficient sales revenue, it would be impossible for a local government to generate more budgetary surplus after it has paid subsidies. Combined with the clue extracted from process tracing, we find that local governments did not attempt to receive income though selling SOEs; thus, it does not meet the necessary conditions- the first hypothesis fails the hoop test. According to the criteria of the process tracing analysis for causal inference (Bennett 2010), an explanation should be eliminated once it fails the hoop test. Therefore, we reject the first hypothesis.

\subsection{Testing the Second Hypothesis}

In this part, we will test the second hypothesis, which assumes that post-privatized firms could contribute significantly more tax revenue to the local government, and with this revenue, China's local governments could have the fiscal surplus after paying subsidies. Normally, a firm's increased profits would account for higher tax contributions; thus, improving the profitability of privatized SOEs is a necessary precondition implied by the second hypothesis. The income of tax revenue could be treated as an intervening variable, which promotes the privatization action (independent variable) and finally leads to an increase in a government's fiscal revenue (dependent variable).

After privatization, a majority of post-privatized firms showed improved operational status. According to the data released by NBS, from 1998 to 2000, the accumulated deficits of industrial enterprises decreased from 120 billion yuan to below 80 billion yuan. The national asset-to-liability ratio declined from 64.26 to $59.6 \%$ in 2000. In Heze, 203 of the 249 SMEs were privatized between 1997 and 2000. Ninety percent of them recovered production, and by 2001, some firms stated earned profits (Shao 2014). Production efficiency significantly improved after privatization. As per the several interviews with post-privatized firms in Changsha, their managers said that the enthusiasm of workers had been much improved: "When workers employed at SOEs, everyone only finished his bask work task, while through importing performance evaluation system after privatization, they are much more 
Table 5 Hoop test

H2. Due to increased tax contributions of privatized enterprises, China's local governments could have a fiscal surplus after paying subsidies

Clue. The production efficiency and profitability of SOEs were improved after privatization reform

Inference. As the production efficiency and profitability were improved, local governments might have a chance to receive increased tax revenue

Summary. With a strong interpretation, $\mathrm{H} 2$ passes this hoop test

dedicated to working", a manager reported (Luo 2008). Therefore, even though postprivatized firms could not get rid of losses immediately, their production efficiency and profitability were improved through privatization.

Based on this evidence, we can inspect the second hypothesis through the hoop test, and Table 5 reflects our inference process. The second hypothesis assumes that post-privatized firms will contribute more tax revenue to local governments. Hence, improved performance must be a precondition for increased tax contribution (Megginson and Netter 2001). In other words, if economic performance rarely improved after privatization, it would be unnecessary to continue inspecting the second hypothesis. As production efficiency and profitability were enhanced after privatization, local governments may have had the possibility to receive increased tax revenue; thus, the second hypothesis passes the hoop test. However, while passing the hoop test cannot confirm a hypothesis, it does increase its possibility. Therefore, we will continue to inspect the second hypothesis.

Even though a firm's productive and operational efficiency appeared to improve, it was an illusion to some extent. Looking at China's SOE reform, during the process of privatization, a significant amount of "surplus" workers would be laid off at the same time. There were various ways to fire redundant workers, such as maiduan gongling (buyouts) or entering into re-employment service centers (RSCs) (Gu 1999). However, regardless of the method, with a smaller corporative scale, privatized firms would save substantial costs regarding workers' wage payments, administrative expenses, and subsistence allowances. Thus, even though 1997-2000 saw significant improvements in economic performance, many scholars (Bai et al. 2006) do not deny that the apparent economic improvements were, in reality, just due to the substantial decrease in operating costs. For instance, through the large-scale laying off of employees, the number of workers of a post-privatized textile firm in Heze decreased from 1200 to fewer than 400 (Shao 2014). In other words, the incomes of post-privatized firms did not show a significant increase; instead, their operational costs dramatically declined, which resulted in the apparent profitability. Thus, excluding the saved expenses, we cannot claim that the performance of these firms immediately improved after privatization.

Consequently, local government's tax revenues did not show a significant increase from 1997 to 1999 . Even though profitability and efficiency seemed to improve after privatization, without a substantial increase in output, there was little difference in incomes between the SOE and the post-privatized firm. Also, because the costs of redundant workers could not suddenly disappear, privatized firms still 
Table 6 Hoop test

H2. Due to increased tax contributions of privatized enterprises, China's local governments could have a fiscal surplus after paying subsidies

Clue. Local governments' tax revenues rarely increased at the initial years after privatization reform

Inference. No matter how much subsidies need to pay for privatized enterprises, without sufficient sales revenue, it would be impossible for a local government to have a fiscal surplus after paying subsidies

Summary. With a strong interpretation, $\mathrm{H} 2$ fails this hoop test

needed to bear one part of the fees for subsidizing laid-off workers (as detailed in the next chapter). Consequently, these firms could not contribute significantly more tax to the local government in the short term. In the following year of implementing the privatization program, Heze's government officials could not receive full salaries yet. Until 2001, Heze's tax revenues barely reached a hundred million yuan, still the minimum within Shandong Province (Shao 2014). Leaving out Heze, Bai et al. (2006) used a regression model to test the effects of privatization among 23 provinces and four municipalities from 1998 to 2003. They found that the increased proportion of non-state-owned enterprises did not lead to a decline in tax revenues, suggesting that it must be impossible for a local government to enjoy booming tax revenues after privatization in the short term.

Therefore, we see that a local government's tax revenues rarely increased in the initial years after privatization. Given this evidence, the second hypothesis could be examined via the hoop test, and Table 6 reflects our inference process. It hypothesizes that with increased tax revenues, local governments could have a fiscal surplus after paying post-privatization subsidies. Regardless of how much of a subsidy must be paid to privatized firms, a substantial increase of tax revenue must be a necessary criterion for this hypothesis. In other words, increased revenue itself would not positively lead to a fiscal surplus; hence, it must be impossible for a local government to generate a fiscal surplus without satisfying this criterion. While not denying that this hypothesis had passed a hoop test because of the improved business condition of post-privatized firms, this study contends that the seeming improvements were just the results of declining operational costs. Consequently, privatized firms did not contribute more tax revenues to local governments in the short term. Considering the revenue-seeking characteristic of local governments, it is credible to claim that the second hypothesis does not meet the necessary conditions-it fails the hoop test. According to the criteria of the process tracing analysis for causal inference (Bennett 2010), a hypothesis should be eliminated once it fails the hoop test. Therefore, we reject the second hypothesis.

\subsection{Testing the Third Hypothesis}

In contrast to the previous two hypotheses that focus on the increase of revenues after privatization, the third assumes that local governments would pay comparatively fewer subsidies after the privatization of SOEs with redundant workers. First, it is worth understanding the form of subsidy after privatization. Re-employment 
service centers (RSCs) in Shanghai were touted as a model for the rest of the country by China's central government in 1997. After Shanghai's government promoted SOE reform in 1995, many SOEs merged were bankrupted or privatized; consequently, over 800,000 workers left their original positions. To prevent social instability, newly laid-off workers were to register with and enter RSCs, which were promoted as an explicit threshold to the market (Bi 1998). RSCs were sector based; for instance, a cluster of reformed textile or horologe SOEs worked together to set up their RSCs, respectively. Even though post-reformed SOEs would take part in establishing RSCs, they only accounted for $25 \%$ of pension payments and the rest was sponsored by Shanghai's city government.

However, it was unrealistic to apply the Shanghai model to the rest of the country, because almost all of the other cities did not have the funds of Shanghai. China's central government initially planned to promote the RSC experiences in Shanghai to other provinces. ${ }^{1}$ However, as Hurst (2009: 71) points out, "Shanghai's success was largely attributable to practices impracticable outside central coast cities with abundant resources". It must be remembered that RSCs and district governments in the Shanghai had made use of substantial tax breaks and low-interest bank loans to help laid-off workers; this was a policy which no other city could likely implement on such a scale. When Hurst interviewed officers in the Shanghai municipal government, a few people admitted that the program's costs were extremely high, and at least two state council officials went so far as to say that it was "fundamentally impossible" to apply the Shanghai model of comprehensive social security almost anywhere else due to insufficient funds (Hurst 2009).

Therefore, when China's central government promoted the RSC model of Shanghai, the majority of governments at the local level were unable to establish RSCs independently. There are many cases which reflect how city governments failed to provide mandated treatments because they lacked funds or resources. Benxi, a prefecture-level city in Liaoning Province, could only afford to have a minority of laid-off workers register with RSCs (Smyth and Zhai 2003). Roughly, one-fifth of workers found some long-term work and the majority of people could not receive the necessary treatment from local governments. Datong and Luoyang, two cities in North-Central China, resembled Benxi in several important respects. Consequently, only workers laid off from some comparatively large SOEs could enter RSCs and the majority of workers lacked such opportunity. The situation was even worse in north-eastern China. Harbin, for instance, even failed to establish RSCs.

Given this evidence, the third hypothesis could be examined via the hoop test and Table 7 reflects our inference process. The third hypothesis assumes that local governments would pay fewer subsidies after privatization. So far, we do not know how a local government could pay fewer subsidies; thus, this evidence is not sufficient to confirm the third hypothesis. However, it satisfies the necessary criterion: if China's local governments had the incentive to transfer the burden of redundant workers to

\footnotetext{
${ }^{1}$ CCP Central Committee and State Council 1998. Notice on the CCP Central Committee and State Council on Starting the Work of Basic Livelihood Protection and Re-employment for Laid-off SOE Workers. (中共中央、国务院关于切实做好国有企业下岗职工基本生活保障和再就业工作的通知). June 9.
} 
Table 7 Hoop test

H3. Due to comparatively fewer subsidy payments, China's local governments could have a fiscal surplus after paying subsidies

Clue. Most of the local governments were unable to establish RSCs independently

Inference. Local governments were hard to solve the problem independently and must ask for help. Hence, they have an incentive to transfer the burden of redundant workers to other entities through privatization reform

Summary. H3 passes this hoop test

other entities through privatization, a precondition is that local governments barely solved this problem and thus had to ask other entities for help. Only in the circumstance that local governments suffered huge fiscal pressures would they be motivated to transfer these costs to other entities, and then privatization may be a feasible way forward. In other words, supposing that each local government had sufficient funds like Shanghai, it would be unnecessary for them to escape the responsibility of subsidizing laid-off workers. Therefore, this evidence satisfies the necessary condition for accepting the third hypothesis, which passes the hoop test. According to Bennett (2010), passing the hoop test affirms the relevance of the hypothesis but does not confirm it. Thus, we will continue to test the third hypothesis by other means.

At the 15th Communist Party Congress in 1997, China's central government gave a clear direction that local government should build its re-employment agency based on the framework of the RSCs in Shanghai. However, China's central government had to take part in the construction of RSCs. As mentioned above, almost all the local governments were unable to accomplish their program alone. The central government quickly realized this status and found that it was "fundamentally impossible" to apply the Shanghai model to the rest of country. Confronting the plight of RSCs at the local level, the central government decided to assist them. Fan (2002) finds that there was a bargain between China's central and the local governments, wherein game theory explained their objective functions, respectively. Because local governments could not afford the RSCs by themselves, virtually millions from surplus labor forces would flow into the market, which could not absorb such huge numbers of people, causing social chaos and instability. Thus, China's central government calculated the potential costs if it did not assist local governments. Once the number of required aids was lower than the possible cost, it was a good deal for the central government to assist local governments.

Hence, the central government decided to assist local governments to solve the burden of redundant workers. In September 1997, China's Communist Party and State Council published the No. 10 (1997) official document, ${ }^{2}$ which clarified the relevant responsibilities among post-reformed firms, local governments, and the

\footnotetext{
${ }^{2}$ CCP and State Council 1997. Supplementary Notice on the State Council on the Relevant Issues about the Pilot Implementation of the Merger and Bankruptcy of State-owned Enterprises in Some Cities and the Reemployment of Workers. (国务院关于在若干城市试行国有企业兼并破产和职工再就业有关问 题的补充通知). March 2.
} 
central government. Most importantly, No. 10 (1997) entrenched a formal institution-the "san-san" ("three-thirds") arrangement. Based on this arrangement, onethird of their funding would come from post-reformed SOEs, one-third from local governments, and one-third from the central government. In the next year, the Central Committee and State Council issued the "Work Conference on Basic Livelihood Protection and Re-employment of Laid-off Workers in SOEs" in May. After June 1998, the local government and firms would not solely fund the RSCs anymore, as the central government would largely support their work.

Nevertheless, in some poor cities where firms and local governments could not contribute their shares, the central government sometimes had to pay more than onethird of the funds. The central government initially refused to pay into RSCs that lacked local government financing; however, after it understood that it was the local government's genuine inability rather than unwillingness, its attitude changed. For instance, Chongqing is a south-western city in China, where, in 1998, many textile SOEs were reformed; consequently, nearly 500,000 laid-off workers entered textile RSCs. Due to woefully inadequate funding, the Chongqing government and firms could only afford 200,000 people's basic allowance. When then-minister Zhu Rongji asked them to solve this problem by themselves, some of Chongqing's officers and firm managers protested (Zhu 2001), saying, "when we force laid-off workers to leave their original positions, a lot of them already get angry, if we cannot pay subsidies anymore, they must throw us into the Yangtze river!" Chongqing's plight created a discussion, and the central government eventually tried to remedy these problems. Most importantly, it agreed to pay some portion or all of the one-third shares of the local government or firms in distress.

In addition to assisting RSCs, China's central government also decided to construct a sound social insurance system, which could be treated as an indirect way to disperse pressure on local governments. As Lin and Tan (1999) claim, without a sound social insurance system, redundant workers would continue being a policy burden, regardless of whether SOEs were privatized or not. China's central government also realized that the RSC was just a transitional step; the fundamental way to solve the problem was to construct a sound insurance system. In July 1997, the State Council issued "Decisions about Constructing the Basic Endowment Insurance System for Enterprise Employees", clarifying the mechanism, range, and proportion of China's insurance system. ${ }^{3}$ Before 2000, China's central government had already allocated 200 million yuan for this program. The social insurance system had some overlapping functions with RSCs, and it gradually replaced the role of RSCs in 2004 (Hurst 2009). Thus, even though constructing a social insurance system did not directly aid local governments, it did at least disperse the pressures of RSCs.

Therefore, through analyzing official documents, interviews, and case studies, we find evidence that China's central government aided local governments in direct or indirect ways. The third hypothesis could be inspected through the smokinggun test, and Table 8 reflects our inference process. With the san-san (three-thirds)

\footnotetext{
${ }^{3}$ State Council 1997. State Council on the Establishment of a Unified Basic Endowment Insurance System for Enterprise Employees. (国务院关于建立统一的企业职工基本养老保险制度的决定). \#26.
} 
Table 8 Smoking-gun test

H3. Due to comparatively fewer subsidy payments, China's local governments could have a fiscal surplus after paying subsidies

Clue. China's central government aided local governments, either in the direct or indirect way

Inference. Through privatization reform, a local government could have a chance to transfer the costs to the central and consequently paid fewer subsidies

Summary. With a strong interpretation, $\mathrm{H} 3$ passes this hoop test

arrangement, the central government shared the responsibility with the local governments; with necessary aids, the central government helped local governments or firms in distress, and the construction of insurance system dispersed the pressures of RSCs. The combined weight of these clues illustrates that, through privatization, a local government could have the chance to transfer the costs to the central government and consequently paid fewer subsidies. Therefore, the third hypothesis passes the smoking-gun test and could be substantially strengthened based on the framework of Bennett (2010).

Lastly, we should not ignore that local governments still had some informal methods to alleviate the pressures of redundant workers. Because few cities had funds, it would be impossible for their RSCs to afford all the laid-off workers. Consequently, some local governments would adopt particular policies to shunt laid-off workers. The most popular one was the buyout, maiduan gongling. The mechanism of buyouts is that reformed firms give laid-off workers an amount of money at one time to compensate their losses and then the labor relation between firm and worker is terminated (Hurst 2009). Bought-out workers received one-time severance payments, usually based on their years of employment (gongling) at homologous SOEs. After that, laid-off workers had to feed themselves and they could not claim money or benefits from the company. Hence, such a policy alleviated the burden of governments when they promoted the privatization of SOEs.

Even though a buyout policy attracted some criticisms, it was still executed in many cities. Because the amount of compensation was very low, it was scarcely enough for bought-out workers. For instance, when a steelwork factory was privatized in 1997 in Harbin, Heilongjiang Province, its workers could only receive compensation per the standard of 500 yuan per year (Wu 2007). A worker who had worked for 15 years at this steelwork could only get 7500 yuan of compensation when he left the firm. Thus, many officials and scholars criticized this policy, saying that it was just "letting people out" without "buying" anything. As Wu (2007) argues, these laid-off workers were dedicated to their work and did not make any mistakes, so it was unfair to let them suffer the cost of reform. However, although some local governments may have shirked their responsibility, it was a reality that the redundant workers were unaffordable for the majority of them. Without privatization and the buyout of laid-off workers, weak SOEs would cause even more costs in the future.

The implementation of maiduan gongling in Zuoquan County, Shanxi Province, is a representative case to illustrate a local government's dilemma. Zuoquan is an 
Table 9 Straw-in-the-wind test

H3. Due to comparatively fewer subsidy payments, China's local governments could have a fiscal surplus after paying subsidies

Clue. Local governments could terminate labor relations with redundant workers by maiduan gongling (buyouts)

Inference. After labor relations were terminated, these bought-out people had to feed themselves in the future, which released the policy and fiscal burden of the local government

Summary. With a weak interpretation, H3 passes this Straw-in-the-wind test

impoverished county in the south-eastern portion of Shanxi province; in the 1990s, almost all the SOEs were on the edge of bankruptcy. After 1997, the new county government decided to reform its SOEs and recover Zuoquan's economy. However, the most severe challenge impeding the privatization program was how to compensate redundant laid-off workers (Shao 2014). Without sufficient funds, it was impossible to construct a sound RSC. Alternatively, through selling the assets of SOEs, Zuoquan's government compensated bought-out workers for an average of 8000 yuan per person. Zuoquan's country clerk communicated with the workers' representative, saying,

Of course you can reject buyouts contract and the privatization program can be denied, however, the annual losses of SOEs will continue to erode net assets. You could get 8000 yuan compensation this year, whereas in the next years you may only get 6000 yuan, and the year after next year only left 4000 yuan per person. (Shao 2014: 147).

Laid-off workers eventually had to compromise with the government, and they also gradually realized that denying the SOEs' reform did not fit anyone's interest. Finally, through communicating with the Zuoquan's country government, many workers accepted the buyout contract ${ }^{4}$ and terminated their labor relations with the original SOEs.

Through tracing the case of Zuoquan, we obtain an important clue that local governments could terminate labor relations with redundant workers by maiduan gongling (buyouts). Consequently, the third hypothesis could be examined through the straw-in-the-wind test, and Table 9 reflects our inference process. The strawin-the-wind test provides neither a necessary nor a sufficient criterion for accepting a hypothesis, although it could increase plausibility. This clue is neither necessary nor sufficient to confirm the third hypothesis, in that we cannot directly claim that a local government could transfer the cost of SOEs to workers through buyouts. Compared to RSCs, buyouts are not a mainstream method to solve the problem of laid-off workers. Also, local governments still needed to pay a lot of money to bought-out people, and subsidy payments did not decrease, at least in the short term.

\footnotetext{
${ }^{4}$ Zuoquan County Government, Shanxi Province 1999. Zuoquan Country on Specific Operational Methods about Straightening out the Labor Relationship. (左权县关于职工身份劳动关系的具体操作办法).
} 
Table 10 Doubly decisive test

H3. Due to comparatively fewer subsidy payments, China's local governments could have a fiscal surplus after paying subsidies

Clue. (a) most of the local governments were unable to establish RSCs independently; (b) China's central government aided local governments, either in the direct or indirect way; (c) local governments could terminate labor relations with redundant workers by maiduan gongling (buyouts)

Inference. The combined weight of these three tests strongly support the third hypothesis; hence, it is confident to claim that China's local governments could transfer the cost of policy burden to other entities and consequently paid fewer subsidies through privatization reform

Summary. With a strong interpretation, H3 passes this Doubly decisive test

However, after labor relations were terminated, these bought-out people had to feed themselves in the future, which released the policy and fiscal burden of the government in the long term. Thus, even though the third hypothesis cannot be confirmed by this clue, its plausibility is increased after passing the straw-in-the-wind test.

Therefore, the third hypothesis could pass the doubly decisive test through multiple tests, and the Table 10 refelects the inference process. We successfully traced three clues by analyzing official documents, interviews, and case studies: (a) a majority of local governments were unable to establish RSCs by themselves; (b) China's central government aided local governments, in direct or indirect ways; (c) local governments could terminate labor relations with redundant workers by maiduan gongling (buyouts). With these three clues, the third hypothesis passes the hoop test (Table 7), the smoking-gun test (Table 8), and the straw-in-the-wind test (Table 9). The combined weight of these three tests strongly supports the hypothesis; thus, we can confirm that China's local governments could transfer the cost of policy burden of redundant workers to other entities and consequently pay fewer subsidies after the privatization of SMEs. Passing the doubly decisive test means that the third hypothesis is fundamentally confirmed, and the other two hypotheses can be eliminated (Table 10).

\section{Discussion and Conclusion}

This paper targets a puzzle that previous articles have mentioned but given insufficient attention. Even though the Chinese privatization reform has been intensively discussed, few scholars have combined the explicit material benefits and the continued subsidies in the analysis. Bai et al. (2006) notice the impacts of massive laidoff workers on social stability and point out that the subsidy payments for SOEs are unavoidable even after the privatization. However, their analysis cannot explain, under the condition of continued subsidy payments, why China's local governments still had such strong incentives to privatize SMEs. The massive scale of the privatization of SMEs suggests that China's local governments de facto gained fiscal surplus after the privatization; however, how they could accomplish this is rarely explained. Thus, in this paper, I investigated the mechanism about how China's local 
governments could obtain fiscal surplus though privatizing small and medium-sized SOEs.

My findings reveal that as local governments could transfer part of the policy burden to the central government or the redundant workers themselves, they would pay comparatively fewer subsidies after the privatization. Considering the comparative advantages of qualitative analysis, I adopted the method of process tracing and causal inference to test the three hypotheses. The first and second hypotheses were rejected because they failed to pass the hoop test, whereas the third hypothesis passed one hoop test, one smoking-gun test, and one straw-in-the-wind test. As Bennett (2010: 211) notes, "single tests that accomplish this are rare in social science, but this leverage may be achieved by combining multiple tests, which together support one explanation and eliminate all others". Hence, the combined weight of these three tests strongly supports the third hypothesis: with fewer subsidy payments, they can obtain fiscal surplus, representing an incentive for the local government.

Empirically, this article is a significant supplement to the work of Bai et al. (2005). Using a panel dataset of 26,153 SOEs in China from 1995 to 1997, Bai et al. (2005) found that even taking the impacts of redundant laid-off workers into account, China's local governments still had strong willingness to privatize SOEs in 1997. This article explains why they had such strong motivation and found the mechanism of how the local governments could obtain fiscal surplus under the condition of continued subsidy payments. Given the revenue-seeking characteristic of the local governments, the fiscal surplus was achieved neither from sales revenues nor tax revenues; instead, China's local governments could transfer the cost of policy burden to other entities and consequently pay fewer subsidies after the privatization, which in turn resulted in the fiscal surplus. Thus, the findings of this article can help people to understand the behaviors of China's local governments in the period between 1997 and 1999.

Some criticisms may arise regarding the discovered mechanism. First, it is reasonable to suppose that the motivations of the local government were attributed to implicit material interests, like the gains of corruption, rather than pursuing the fiscal surplus. Even though I do not deny the losses of state assets caused by corruption in the privatization process, I believe that it is not the primary story for the privatization in the period between 1997 and 1999. As the clues presented in testing the first hypothesis, the majority of SMEs had extremely high asset-liability ratios. Thus, considering the suffered liabilities after the privatization, the net assets of SOEs shrank largely, which hardly generates the motivation for corruption. Also, the open historical archives reveal that corruption was rarely found in the late-1990s privatization. A typical case is that when Heze city privatized SOEs in 1997, the central government initially suspected that whether Heze officials took the form of privatization to peculate state assets (Shao 2014). Hence, the then-premier Zhu Rongji arranged a group of officials from the State Council to investigate this matter. After detailed investigations, the central officials did not find any evidence of the corruption of local officials in Heze, which made them aware that the local government's motivation for privatization was primarily attributed to fiscal reasons.

Regarding the second hypothesis, it may seem confusing that there was no efficiency gain pre- and post-privatization. As Asaftei and Parmeter (2010) argue, 
privatized SOEs get better access to bank loans or FDI, which would show up as improved benefits to the local government. Also, privatized SOEs may enjoy a monopoly on rent from a consolidated market, which means that profit may increase even if performance or productivity remains unchanged. However, I must re-emphasize the range and horizon of this research. While not denying that large SOEs would generate monopoly advantages after privatization, SMEs are clustered in the competitive sectors regarding the textile, footage, and light industries, which would be impossible for privatized firms to obtain any monopoly advantage in. Furthermore, this article only investigated the period between 1997 and 1999, wherein privatized firms did not develop fundamentally; thus, their seemingly improved profitability and efficiency indeed resulted from decreasing operational costs.

As far as the third hypothesis is concerned, I believe that the endogeneity problem is not significant in the analysis. People may suspect that for a given SOE, its taxation contributions and received subsidies are highly correlated, because with little tax revenue, local governments found it difficult to significantly subsidize SOEs. Under this condition, even after the privatization, the so-called transferred subsidy payments were meagre, which could not have contributed to the fiscal surplus. However, for the local governments, the subsidies to the SOEs were independent of their tax revenues in the early 1990s. The multi-task features of the SOEs suggest that the state would be responsible for the SOE's losses that arise from the policy burdens. Thus, the government would be obliged to give additional credits or other resources to subsidize loss-making SOEs. In other words, the amount of received subsidies would highly depend on the size of an SOE's policy burdens rather than on its operating performance. Also, before the re-centralization of the fiscal and monetary system, China's local governments enjoyed considerable autonomy in intervening in bank lending, which means that they also could significantly subsidize SOEs at that time.

The findings of this article have important theoretical contributions. First, this article explains the conflicting attitudes regarding the pace of privatization between China's central government and local governments. Even though a majority of local governments could not afford the costs of laid-off workers after privatization, they could expect that the central government would not refuse to support them in establishing RSCs if in distress; thus, China's local governments would have strong incentives to promote privatization. From the central government's perspective, an excessively fast pace of privatization would not resolve the problems of a socialist planned economy in reality. Covertly, it would result in pressure for the central government to assist local governments, given its fiscal budget. Thus, after clarifying the reason for the local government's fiscal surplus, it is not difficult to understand why China's central government and local governments had conflicting interests in the process of privatization.

In addition, a significant contribution of this paper is re-evaluating the role of China's local governments during the process of privatization. Because the privatization of SOEs was firstly implemented at the city level, local governments are often treated as pioneers of SOE reform. Many people appreciate their contributions to pushing China's economic transition, and they think that China's SOE reform was a "bottom-up reform" or "wisdom of grassroots". However, 
while not neglecting the contributions of local governments, the findings suggest that China's local governments were motivated to transfer the cost of policy burden regarding redundant workers to other entities through privatization. Indeed, the central government shared the costs of policy burden by giving necessary aid, helping to construct RSCs and setting up social insurance systems. Therefore, once we understand how China's local governments could obtain more fiscal revenue after privatization, we must admit that, as revenue-seeking entities, local governments did not make as many contributions as people have previously claimed. After all, the original intention of the local governments was to escape the responsibility of paying subsidies rather than solve the problem of bad performance in SOEs. In contrast, China's central government and laid-off workers themselves, to some extent, should be given more merit for their contributions.

Finally, further research should focus on the long-term effects of the privatizations in the late 1990s. Fioretos et al. (2016) claim that politics is a structured process in which the outcomes are coordinated by variables crossing time and space. Following the logic of historical institutionalism, it is worth examining if the privatization behaviors in the 1990s could be treated as a critical juncture and whether the path dependency effects exist in the subsequent privatization reform. Because of the de facto federalism in China, the local governments exclusively handle most economic issues within their jurisdiction. Given the unfinished SOE reform, the bargaining between the central and local governments on the SOE issues may continue. Thus, further research on SOE reform should pay attention to the self-interest characteristic of the local governments and carefully investigate how the local governments bargain with the central government in the process.

Acknowledgements The author thanks Peter Kingstone, Nahee Kang, Kun-Chin Lin, Beichen Qin, and two anonymous reviewers for their helpful comments on earlier versions of this article.

Open Access This article is distributed under the terms of the Creative Commons Attribution 4.0 International License (http://creativecommons.org/licenses/by/4.0/), which permits unrestricted use, distribution, and reproduction in any medium, provided you give appropriate credit to the original author(s) and the source, provide a link to the Creative Commons license, and indicate if changes were made.

\section{References}

Asaftei, G., and C.F. Parmeter. 2010. Market power, EU integration and privatization: The case of Romania. Journal of comparative economics 38 (3): 340-356.

Bai, C.E., J. Lu, and Z. Tao. 2006. The multitask theory of state enterprise reform: Empirical evidence from China. American Economic Review 96 (2): 353-357.

Bai, C.E., Lu, J., and Tao, Z. 2005. Divergent interests between central and local governments: testing theories of public ownership. Hong Kong Institute of Economics and Business Strategy Working Papers, vol. 1143.

Bennett, A. 2010. Process tracing and causal inference. In Rethinking social inquiry: Diverse tools, shared standards, eds. Brady, H.E., \& Collier, D. Lanham, Md: Rowman \& Littlefield Publishers. 
Bennett, A., and J.T. Checkel. 2012. Process Tracing: From Philosophical Roots to Best Practices. Simons Papers in Security and Development, No. 21/2012, School for International Studies, Simon Fraser University, Vancouver, BC, Canada, June 2012. ISSN 1922-5725

Bennett, A., and J.T. Checkel (eds.). 2014. Process tracing: From metaphor to analytic tool. Cambridge: Cambridge University Press.

Bi, G. 1998. Unemployment, layoffs and reemployment programs in China-A case study of Shanghai Reemployment Service Center program and its adaptation. UMI Microform, 1417375.

Brada, J.C. 1996. Privatization is transition-Or is it? Journal of Economic Perspectives 10 (2): 67-86.

Cao, Y., Y. Qian, and B.R. Weingast. 1999. From federalism, Chinese style to privatization, Chinese style. Economics of Transition 7 (1): 103-131.

CCP and State Council. 1997. Supplementary notice on the state council on the relevant issues about the pilot implementation of the merger and bankruptcy of state-owned enterprises in some cities and the reemployment of workers. (国务院关于在若干城市试行国有企业兼并破产和职工再就业有 关问题的补充通知). March 2.

CCP Central Committee and State Council. 1998. Notice on the CCP central committee and state council on starting the work of basic livelihood protection and re-employment for laid-off SOE workers. (中 共中央、国务院关于切实做好国有企业下岗职工基本生活保障和再就业工作的通知). June 9.

Chong, A., and F.L. De Silanes (eds.). 2005. Privatization in Latin America: myths and reality. Washington, DC: World Bank Publications.

Collier, D. 2011. Understanding process tracing. PS: Political Science and Politics 44 (4): 823-830.

Coase, R., and N. Wang. 2012. How China became capitalist. Basingstoke: Palgrave Macmillan.

Dong, X.Y., and L. Putterman. 2003. Soft budget constraints, social burdens, and labor redundancy in China's state industry. Journal of Comparative Economics 31 (1): 110-133.

Fan, Wenhui. 2002. Policy burden, ex post efficiency and soft budget constraints, (中国国有企业的预算 软约束问题). The Peking University China Centre for Economic Research (CCER), Beijing.

Fioretos, O., T.G. Falleti, and A. Sheingate (eds.). 2016. The Oxford handbook of historical institutionalism. Oxford: Oxford University Press.

George, A.L., and A. Bennett. 2005. Case studies and theory development in the social sciences. Cambridge: MIT Press.

Gu, E.X. 1999. From permanent employment to massive lay-offs: The political economy of 'transitional unemployment' in urban China (1993-8). Economy and Society 28 (2): 281-299.

Guo, K., and Y. Yao. 2005. Causes of privatization in China. Economics of Transition 13 (2): 211-238.

Hedström, P., and P. Ylikoski. 2010. Causal mechanisms in the social sciences. Annual Review of Sociology 36: 49-67.

Hurst, W. 2009. The Chinese worker after socialism. Cambridge: Cambridge University Press.

King, G., R.O. Keohane, and S. Verba. 1994. Designing social inquiry: Scientific inference in qualitative research. Princeton: Princeton University Press.

Knight, J., and S. Ding. 2012. China's remarkable economic growth. Oxford: Oxford University Press.

Lardy, N.R. 1998. China's unfinished economic revolution. Washington, DC: Brookings Institution Press.

Li, D., and F. Liu. 2004. Why do governments dump state enterprises? Evidence from China. Governance, regulation, and privatization in the Asia-Pacific Region, NBER East Asia seminar on economics, vol. 12, 211-230. Chicago: University of Chicago Press.

Li, S., S. Li, and W. Zhang. 2000. The road to capitalism: Competition and institutional change in China. Journal of Comparative Economics 28 (2): 269-292.

Lin, J.Y., and G. Tan. 1999. Policy burdens, accountability, and the soft budget constraint. American Economic Review 89 (2): 426-431.

Lin, J.Y., F. Cai, and Z. Li. 1998. Competition, policy burdens, and state-owned enterprise reform. The American Economic Review 88 (2): 422-427.

Liu, G.S., P. Sun, and W.T. Woo. 2006. The political economy of Chinese-style privatization: Motives and constraints. World Development 34 (12): 2016-2033.

Luo, Fangliang. 2008. The reform of Changsha's state-owned enterprises in memoir, (跨越: 长沙国企改 革两个置换纪实). China Economic Press, (中国经济出版社).

Megginson, W. L., and J. M. Netter. 2001. From state to market: A survey of empirical studies on privatization. Journal of Economic Literature 39(2): 321-389. https://doi.org/10.1257/jel.39.2.321

Montinola, G., Y. Qian, and B.R. Weingast. 1995. Federalism, Chinese style: the political basis for economic success in China. World Politics 48 (01): 50-81. 
Naughton, B. 2008. A political economy of China's economic transition. In China's Great Economic Transformation, eds. Brandt L., and T. Rawski, 91-135. Cambridge: Cambridge University Press. https://doi.org/10.1017/CBO9780511754234.005.

OECD. 2000. OECD economic surveys: Korea 2000. Paris: OECD Publishing.

Oi, J.C. 1995. The role of the local state in China's transitional economy. The China Quarterly 144: 1132-1149.

Perkins, F. 1998. The costs of China's state-owned enterprises. MOST: Economic Policy in Transitional Economies 9(1):17-33.

Qian, Y., and Roland, G. 1998. Federalism and the soft budget constraint. American Economic Review 88(5): 1143-1162.

Qian, Y., and B. R. Weingast. 1997. Federalism as a commitment to perserving market incentives. The Journal of Economic Perspectives 11(4): 83-92. https://doi.org/10.1257/jep.11.4.83

Qian, Y., and C. Xu. 1993. Why China's economic reforms differ: the M-form hierarchy and entry/expansion of the non-state sector. Economics of Transition 1 (2): 135-170.

Rawski, T.G. 1995. Implications of China' reform experience. The China Quarterly 144: 1150-1173.

Shao, Ning. 2014. The reform of state-owned enterprises in memoir, (国有企业改革实录). Economic Science Press, (经济科学出版社).

Smyth, R., and Q. Zhai. 2003. Economic restructuring in China's large and medium-sized state-owned enterprises: evidence from Liaoning. Journal of Contemporary China 12 (34): 173-205.

State Council, 1997. State council on the establishment of a unified basic endowment insurance system for enterprise employees. (国务院关于建立统一的企业职工基本养老保险制度的决定). \#26.

Van Evera, S. 1997. Guide to methods for students of political science. New York: Cornell University Press.

Wang, Hongling, Li, Daokui, and Lei, Dingming. 2001. Why do government dump state enterprises? Evidence from China, (政府为什么会放弃国有企业的产权). Chinese Academy of Social Sciences, (中国社会科学院).

Williamson, O.E. 2008. The economic institutions of capitalism. In The Political Economy Reader: Markets as Institutions, eds. Barma, N., Barma, N.H., \& Vogel, S.K. Routledge.

Wu, Xiaobo. 2007. Thirty years of agitation, (激荡三十年). New Economic Guide, (新经济导刊) 3:79-79.

Zhang, W. 2009. The 'China Model 'of SOE reform and its challenges. China Economist 4(2). Available atSSRN: https://ssrn.com/abstract=1544336.

Zheng, Y. 2007. De facto federalism in China: Reforms and dynamics of central-local relations (Vol. 7). World Scientific.

Zhou, Qiren. 2008. The way of Changsha, (长沙的路子). Beijing: Peking University Press.

Zhu, Guangchun. 2003, Chronic of the development of Chinese private enterprises, (中国民营企业成长 通鉴). Jinan: Jinan University Press.

Zhu, Rongji. 2001. The memoir of Zhu Rongji, (朱镕基讲话实录). Donegal: The People's Press.

Zuoquan County Government, Shanxi Province. 1999. Zuoquan country on specific operational methods about straightening out the labor relationship. (山西省左权县关于职工身份劳动关系的具体操作 办法).

Yutao Huang is currently a DPhil student in International Relations at the Department of Politics and International Relations, University of Oxford, UK. He holds an M.Sc in Social Research Methods from the London School of Economics and Political Science, as well as an M.Sc in Political Economy of Emerging Markets from King's College, London. His research interests include, but are not limited to the political economy of finance, emerging and transition economies, the developmental state, Chinese politics, and sovereign wealth fund. 